\title{
The Effect of Hyperbaric Oxygen Therapy on Rectal Ulcers after Argon Plasma Coagulation
}

\author{
Ana Laranjo Maria Carvalho Andreia Rei Nuno Veloso Isabel Medeiros
}

Department of Gastroenterology, Hospital Espírito Santo de Évora, Évora, Portugal

\section{Keywords}

Argon plasma coagulation - Chronic radiation proctitis . Hyperbaric oxygen therapy · Argon plasma coagulationinduced rectal ulcer

\section{Abstract}

Chronic radiation proctitis usually develops 3 months after therapy. Despite the lack of standard guidelines regarding treatment, argon plasma coagulation is often a safe and effective endoscopic therapy. However, rectal ulcers are a common complication after argon plasma coagulation. Nevertheless, most patients are asymptomatic and do not require additional monitoring or treatment. We report a case of an argon plasma coagulation-induced ulcer with relevant symptoms and refractory to medical treatment. The patient was treated with hyperbaric oxygen therapy and had complete resolution of the rectal ulcer. Hyperbaric oxygen therapy has shown efficacy in severe chronic proctitis and radiation-induced rectal ulcers, but no clinical report has ever been published on using hyperbaric oxygen therapy for ulcers after argon plasma coagulation. In this case, hyperbaric oxygen therapy was an effective alternative option and can be considered in patients with refractory argon plasma coagulation-induced rectal ulcers.

() 2020 Sociedade Portuguesa de Gastrenterologia Published by S. Karger AG, Basel

karger@karger.com www.karger.com/pjg

Karger"

GOPEN ACCESS
(C) 2020 Sociedade Portuguesa de Gastrenterologia Published by S. Karger AG, Basel

This article is licensed under the Creative Commons AttributionNonCommercial-NoDerivatives 4.0 International License (CC BYNC-ND) (http://www.karger.com/Services/OpenAccessLicense). Usage and distribution for commercial purposes as well as any distribution of modified material requires written permission.

\author{
O papel da oxigenoterapia hiperbárica nas úlceras \\ retais secundárias à terapêutica com árgon-plasma \\ Palavras Chave \\ Árgon-plasma · Proctite rádica crónica $\cdot$ Oxigenoterapia \\ hiperbárica · Úlceras retais secundárias ao árgon-plasma
}

\section{Resumo}

A proctite rádica crónica desenvolve-se habitualmente 3 meses após radioterapia. Não obstante a ausência de recomendações em relação ao tratamento desta patologia, a terapêutica endoscópica com árgon-plasma é segura e eficaz. Contudo, as úlceras retais são uma complicação frequente, apesar da maioria dos doentes serem assintomáticos e não requerem vigilância e/ou tratamento. Os autores apresentam um caso clínico de um doente com o diagnóstico de proctite rádica crónica, submetido a terapêutica com árgon-plasma com posterior desenvolvimento de úlcera retal refratária a tratamento médico conservador. O doente foi submetido a oxigenoterapia hiperbárica com resolução completa da úlcera retal. De acordo com a literatura, a oxigenoterapia hiperbárica apresenta eficácia na proctite rádica crónica grave e nas úlceras retais induzidas por radioterapia. Contudo, a utilização da oxigenoterapia hiperbárica nas úlceras retais secundárias 
a terapêutica com árgon-plasma ainda não foi descrita. Neste caso, a oxigenoterapia hiperbárica foi uma opção terapêutica eficaz, podendo ser considerada nas úlceras retais refratárias secundárias a terapêutica com árgonplasma.

(c) 2020 Sociedade Portuguesa de Gastrenterologia Publicado por S. Karger AG, Basel

\section{Introduction}

Radiation proctitis is a common complication following pelvic radiation therapy. It can be classified either as acute or chronic proctitis based on the time of onset of symptoms after therapy [1]. Chronic radiation proctitis occurs in $5-10 \%$ of patients either as progression from the acute phase, or 3 months after therapy completion. Although not necessarily, it generally occurs in patients who suffered from severe acute proctitis [2]. There are several treatment options, which can range from medical therapy and endoscopic techniques to surgery in the refractory or severe cases [1].

Argon plasma coagulation (APC) is an endoscopic therapy for patients who failed medical treatment and remains one of the techniques most commonly reported [1]. Although it is considered a safe and effective technique, APC can be associated with rectal ulcers as postprocedure complications [3].

In most cases, rectal ulcers are asymptomatic and do not require additional monitoring or treatment [4]. For those who remain symptomatic, treatment guidelines are currently lacking in the literature. While hyperbaric oxygen (HBO) therapy has been reported as an effective treatment strategy in patients with radiation-induced rectal ulcers [5], its use has not been described in APCinduced rectal ulcers. Therefore, this is an original case report on the use of HBO therapy as a treatment of an acute ulcer as a complication after APC.

\section{Case Report}

A 72-year-old man was referred to our institution for management of rectal bleeding for 2 weeks, without other digestive symptoms. His past medical history was significant for hyperlipidemia, type 2 diabetes mellitus, and T2aN0 prostatic cancer treated 8 months earlier with external radiotherapy and chemotherapy. His current medication included simvastatin, vildagliptin, and metfor$\mathrm{min}$. Blood tests revealed a hemoglobin of $8.1 \mathrm{mg} / \mathrm{dL}$ with a mean corpuscular volume of $76 \mathrm{fL}$, white blood count of $6,800 / \mathrm{mm}^{3}$, and platelets of $146,000 / \mathrm{mm}^{3}$.

Argon Plasma Coagulation-Induced Rectal Ulcers

The patient underwent rectosigmoidoscopy which revealed friable and edematous rectal mucosa with multiple angioectasias, consistent with radiation proctitis (Fig. 1).

He began a 4-week course of sucralfate enemas (2 g twice daily), without clinical or endoscopic improvement on reevaluation.

Due to persistence of rectal bleeding and endoscopic signs of radiation proctitis, APC treatment was initiated, which was applied to the bleeding areas of the mucosa with an energy level of 40 $\mathrm{W}$ and gas flow of $1.5 \mathrm{~L} / \mathrm{min}$ (Fig. 2).

After 2 weeks, the patient reported intense proctalgia and worsening of rectal bleeding. A new rectosigmoidoscopy revealed a 10$\mathrm{mm}$ ulcer, located at the site of previous APC therapy, on the anterior circumference of the low rectum (Fig. 3).

The patient resumed topical therapy with sucralfate enemas (2 $\mathrm{g}$ twice daily) and began mesalazine suppositories ( $1 \mathrm{~g}$ daily). As no clinical or endoscopic changes were observed after 8 weeks of topical therapy, the patient was submitted to HBO therapy, having performed 50 sessions over a period of 10 weeks (100 min per session, 5 sessions per week). The rectal ulcer completely healed, but significant improvement of rectal bleeding and radiation proctitis was not observed (Fig. 4, 5). It was decided to maintain therapy with sucralfate enemas. At 6 months, the patient was asymptomatic without anemia.

\section{Discussion}

Rectal ulcers are a common complication after APC treatment, being seen in approximately $50 \%$ of cases that underwent this endoscopic therapy $[4,6]$. The development of rectal ulcers after APC is thought to be an effect of thermal injury to a damaged tissue with poorer healing. There are multiple factors associated with a risk of ulceration such as the method of application, the time interval between treatment sessions, and the flow rate of the argon [4]. However, there is no consensus regarding the optimal APC settings [7]. In a recent systematic review, Peng et al. [7] reported that the electric power setting ranged from 25 to $80 \mathrm{~W}$ (median $50 \mathrm{~W}$ ), with an argon flow rate from 0.6 to $3.0 \mathrm{~L} / \mathrm{min}$ (median $1.5 \mathrm{~L} / \mathrm{min}$ ) in several studies.

Sato et al. [8] showed that a power of $40 \mathrm{~W}$ with $1.2 \mathrm{~L} /$ min gas flow and a coagulation time of $2 \mathrm{~s}$ was associated with an effectively treated submucosal telangiectasia without affecting the deeper underlying muscle layer. Canard et al. [9] reported that almost all complications occurred at power settings above $45 \mathrm{~W}$. Gheorge et al. [10] concluded that there was no statistical significance concerning efficacy and side effects of APC treatment between the 60 and $50 \mathrm{~W}$ power setting. However, rectal stenosis was observed with higher power settings.

In this case, the endoscopy performed after failure of medical treatment confirmed the persistent active hem-

GE Port J Gastroenterol 2021;28:288-291 


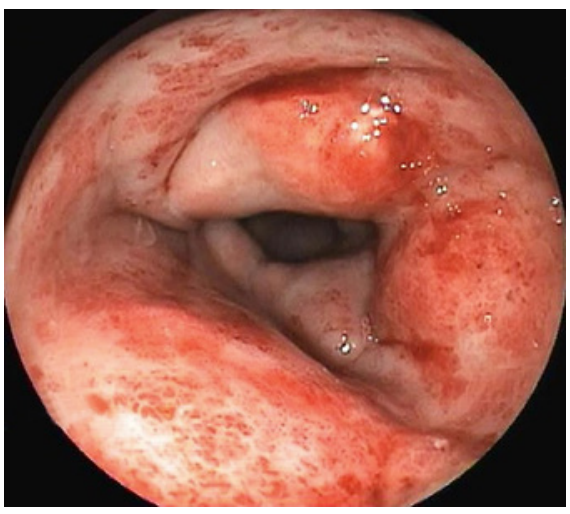

Fig. 1. Radiation proctitis.

Fig. 4. Rectal ulcer after 20 sessions of $\mathrm{HBO}$.

Fig. 5. Complete healing of rectal ulcer after 50 sessions of HBO. No improvement of radiation proctitis.

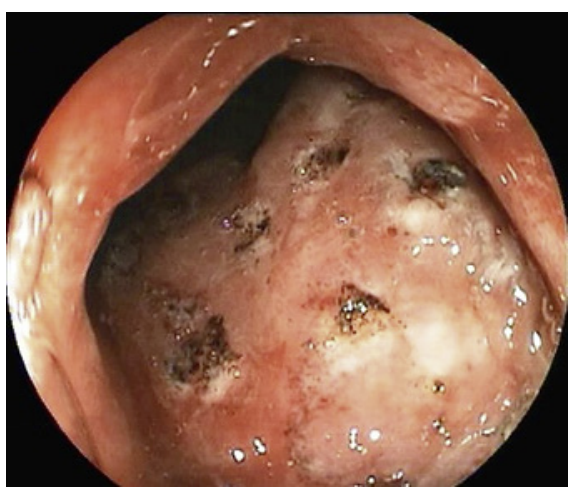

Fig. 2. Argon plasma coagulation.

$$
4
$$

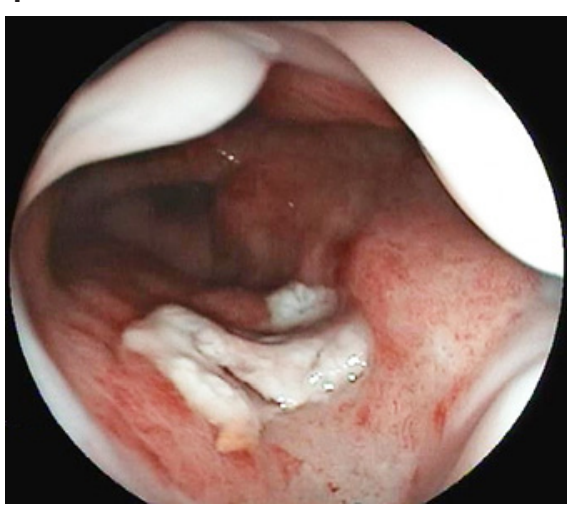

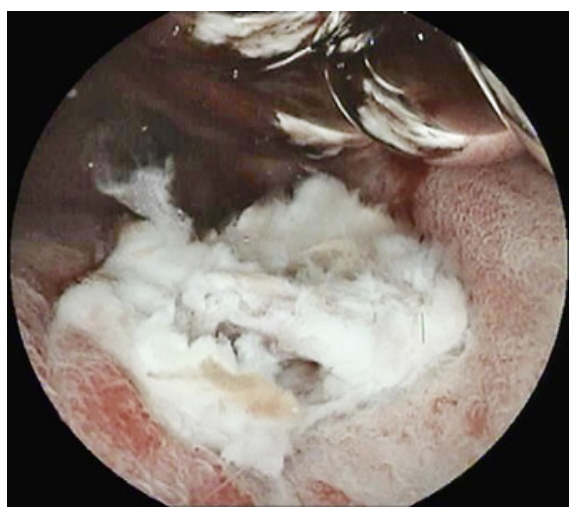

Fig. 3. Ulcer of $10 \mathrm{~mm}$, located at the site of previous APC therapy, on the anterior circumference of the low rectum.

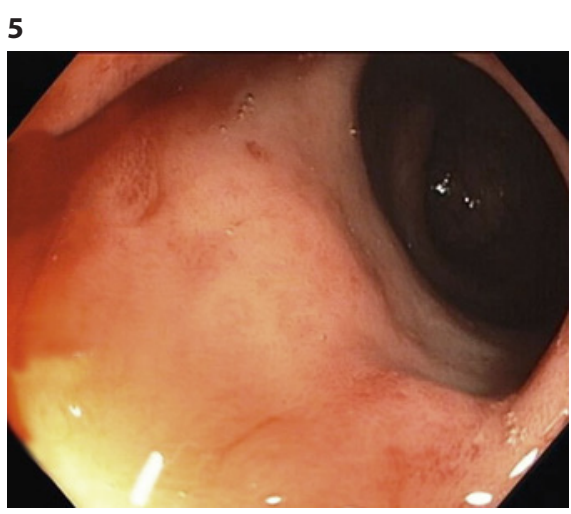

orrhagic radiation proctitis without initial ulcerative lesions, which led us to perform APC therapy. The presence of a rectal ulcer after APC allowed to assume it as a complication of the procedure. The settings seemed appropriate, although the time of coagulation had not been noted, which may be one of the presumed causes for the development of the ulcer after one session of APC. After no clinical and endoscopic improvement with medical treatment for the APC-induced ulcer, we decided to perform $\mathrm{HBO}$ therapy. $\mathrm{HBO}$ therapy has been described as an alternative option for patients with severe radiation chronic proctitis $[1,11,12]$.

In a single randomized controlled trial, Clarke et al. [13] found significant improvement of the healing responses in patients with refractory radiation proctitis. In a systematic review, Feldmeier et al. [14] reported that most articles showed a positive result for the treatment of chronic radiation proctitis, and the authors suggested $\mathrm{HBO}$ therapy as an alternative therapy for cases who need more invasive interventions. Despite the efficacy of HBO therapy in trials [12-14], the evidence is lacking, and more studies are necessary.

$\mathrm{HBO}$ therapy also has a role in radiation-induced rectal ulcers. Recently, Yoshimizu et al. [5] showed complete ulcer resolution among 5 patients with radiation-induced rectal ulcers. This report is limited by the small number of cases, but $\mathrm{HBO}$ therapy was effective in all cases.

In spite of the efficacy of HBO therapy in severe chronic proctitis and radiation-induced rectal ulcers, no clinical report has ever been published on using HBO therapy for ulcers after APC. This may be due to ulcers being usually clinically silent and self-limiting, with no need for treatment.

In this case, HBO therapy was an effective treatment option, and the patient had complete healing of the ulcerative lesions. 


\section{Conclusion}

HBO therapy can be considered a treatment option in patients with refractory APC-induced rectal ulcers.

\section{Statement of Ethics}

The patient has given his informed consent to publish his case (including publication of images).

\section{Conflict of Interest Statement}

None of the authors has any conflicting interests to disclose.

Funding Sources

None of the authors has any financial interests to disclose.

\section{References}

1 Weiner JP, Wong AT, Schwartz D, Martinez M, Aytaman A, Schreiber D. Endoscopic and non-endoscopic approaches for the management of radiation-induced rectal bleeding. World J Gastroenterol. 2016 Aug;22(31): 6972-86.

2 Tabaja L, Sidani SM. Management of Radiation Proctitis. Dig Dis Sci. 2018 Sep;63(9): 2180-8.

3 Koessler T, Servois V, Mariani P, Aubert E, Cacheux W. Rectal ulcer: due to ketoprofen, argon plasma coagulation and prostatic brachytherapy. World J Gastroenterol. 2014 Dec;20(45):17244-6.

4 Ravizza D, Fiori G, Trovato C, Crosta C. Frequency and outcomes of rectal ulcers during argon plasma coagulation for chronic radiation-induced proctopathy. Gastrointest Endosc. 2003 Apr;57(4):519-25.

5 Yoshimizu S, Chino A, Miyamoto Y, Tagao F, Iwasaki S, Ide D, et al. Efficacy of hyperbaric oxygen therapy in patients with radiation-induced rectal ulcers: report of five cases. Dig Endosc. 2017 Sep;29(6):718-22.
6 Chruscielewska-Kiliszek MR, Rupinski M, Kraszewska E, Pachlewski J, Regula J. The protective role of antiplatelet treatment against ulcer formation due to argon plasma coagulation in patients treated for chronic radiation proctitis. Colorectal Dis. 2014 Apr; 16(4):293-7.

7 Peng Y, Wang H, Feng J, Fang S, Zhang M, Wang F, et al. Efficacy and Safety of Argon Plasma Coagulation for Hemorrhagic Chronic Radiation Proctopathy: A Systematic Review. Gastroenterol Res Pract. 2018 Feb;2018: 3087603.

8 Sato Y, Takayama T, Sagawa T, Hirakawa M, Ohnuma H, Miyanishi K, et al. Argon plasma coagulation treatment of hemorrhagic radiation proctopathy: the optimal settings for application and long-term outcome. Gastrointest Endosc. 2011 Mar;73(3):543-9.

9 Canard JM, Védrenne B, Bors G, Claude P, Bader R, Sondag D. [Long term results of treatment of hemorrhagic radiation proctitis by argon plasma coagulation]. Gastroenterol Clin Biol. 2003 May;27(5):455-9.

10 Gheorghe C, Gheorghe L, Iacob R, Iacob S, Simionov I, Băncilă I. Argon plasma coagulation for radiation proctitis. Rom J Gastroenterol. 2003 Jun;12(2):107-12.
11 Tahir AR, Westhuyzen J, Dass J, Collins MK, Webb R, Hewitt S, et al. Hyperbaric oxygen therapy for chronic radiation-induced tissue injuries: australasia's largest study. Asia Pac J Clin Oncol. 2015 Mar;11(1):68-77.

12 Oscarsson N, Arnell P, Lodding P, Ricksten SE, Seeman-Lodding H. Hyperbaric oxygen treatment in radiation-induced cystitis and proctitis: a prospective cohort study on patient-perceived quality of recovery. Int J Radiat Oncol Biol Phys. 2013 Nov;87(4):670-5.

13 Clarke RE, Tenorio LM, Hussey JR, Toklu AS, Cone DL, Hinojosa JG, et al. Hyperbaric oxygen treatment of chronic refractory radiation proctitis: a randomized and controlled double-blind crossover trial with long-term follow-up. Int J Radiat Oncol Biol Phys. 2008 Sep;72(1):134-43.

14 Feldmeier JJ, Hampson NB. A systematic review of the literature reporting the application of hyperbaric oxygen prevention and treatment of delayed radiation injuries: an evidence based approach. Undersea Hyperb Med. 2002;29(1):4-30. 